\title{
Final Technical Report
}

on

\section{Atmospheric Ozone as a Climate Gas}

Prepared for:

Environmental Sciences Division

Office of Biological and Environmental Research

U.S. Department of Energy, ER-74

19901 Germantown Road

Germantown, MD 20874-1290

(DOE Grant No. DE-FG02-94ER61868)

\section{Prepared by:}

Wei-Chyung Wang

Principal Investigator

Atmospheric Sciences Research Center

State University of New York

251 Fuller Road

Albany, New York 12203

(SUNYA File No. 320-2550A)

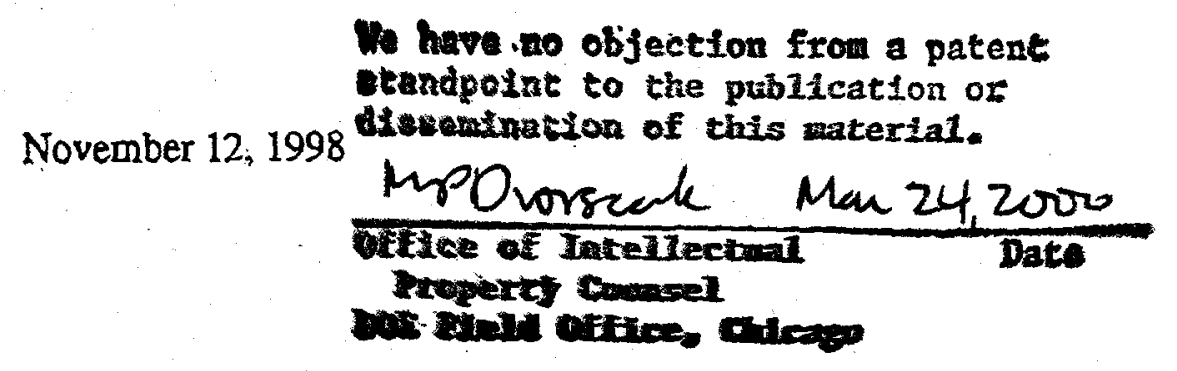




\section{DISCLAIMER}

This report was prepared as an account of work sponsored by an agency of the United States Government. Neither the United States Government nor any agency thereof, nor any of their employees, make any warranty, express or implied, or assumes any legal liability or responsibility for the accuracy, completeness, or usefulness of any information, apparatus, product, or process disclosed, or represents that its use would not infringe privately owned rights. Reference herein to any specific commercial product, process, or service by trade name, trademark, manufacturer, or otherwise does not necessarily constitute or imply its endorsement, recommendation, or favoring by the United States Government or any agency thereof. The views and opinions of authors expressed herein do not necessarily state or reflect those of the United States Government or any agency thereof. 


\section{DISCLAIMER}

Portions of this document may be illegible in electronic image products. Images are produced from the best available original document. 


\begin{abstract}
This report summarizes the major research accomplishments of the project "Atmospheric Ozone as a Climate Gas" for the period July 1, 1994-March 31, 1998. The report is divided into three sections: research summary, publications and participation of graduate students.

The objectives of the research program were: (1) to improve understanding of the physical, chemical and dynamical processes that control mid-latitude $\mathrm{O}_{3}$ in the lower stratosphere and free troposphere; and (2) to develop improved predictions of future $\mathrm{O}_{3}$ changes in these regions and their influence on (and response to) future climate changes. The research team includes a subcontractor, Professor Ivar Isaksen of the University of Oslo.
\end{abstract}

\title{
1. Research Summary
}

\subsection{Climatic Effects of Observed Oxone Changes}

The observed $\mathrm{O}_{3}$ climatology, together with radiation and climate models, were used to evaluate the importance of atmospheric $\mathrm{O}_{3}$ to radiation balance, and to study how the observed $\mathrm{O}_{3}$ changes during the decades 1980 s and 1990 s affect radiative forcing and climate as well as their comparison with increasing other greenhouse gases. [Shine et al., 1995; Liang and Wang, 1995; Mohnen et al., 1995a, b; Wang et al., 1995a, b]

\subsection{Climate-Chemistry Interaction}

Climate-chemistry interactions were studied based on the NCAR GCMs (CCM1, GENESIS, CCM3) and the University of Oslo's chemical-transport models (CTMs). First, the CTMs were used to calculate tropospheric $\mathrm{O}_{3}$ distribution using a variety of emission scenarios for $\mathrm{NO}_{x}, \mathrm{HC}$, and $\mathrm{CO}$. Next, the $\mathrm{O}_{3}$ and other gases consistently calculated from the CTMs were used as input to radiation models to study the effect on radiative forcing and UV flux reaching the surface. These experiments were conducted for both the current climate state and the global warming climate state induced by increasing concentrations of greenhouse gases (such as $\mathrm{CO}_{2}, \mathrm{CH}_{4}, \mathrm{~N}_{2} \mathrm{O}$ and CFCs). These studies were summarized in several publications [Berntsen et al, 1996, 1997; Fuglestvedt et al., 1995, 1996, 1997; Wang et al., 1997]

A 2-D CTM of the global troposphere was used to study the chemical response to: (1) increased UV radiation from stratospheric $\mathrm{O}_{3}$ depletion and (2) increased temperature and $\mathrm{H}_{2} \mathrm{O}$ densities caused by global waming as simulated from GCM. Increased UV radiation increases the photolysis rates for several tropospheric gases, in particular $\mathrm{O}_{3}$. This leads to enhanced levels of odd hydrogen and reduced concentrations of tropospheric $\mathrm{O}_{3}$. Increases in temperature and water vapor densities reduce the levels of tropospheric $\mathrm{O}_{3}$ through temperaure dependent reaction rates and increased production of odd hydrogen. In both cases, the $\mathrm{CH}_{4}$ levels are also reduced. Thus the results indicate that the considered mechanisms constitute damping effects on global warming. For a global warming of $3.9^{\circ} \mathrm{C}$ and column moisture increase $27 \%$ calculated in Wang et al. (1992, Inadequacy of effective $\mathrm{CO}_{2}$ as a proxy to assess the greenhouse effect of 
other radiatively active gases. (Geophys. Res Lett, 12, 1375-1378), the levels of tropospheric $\mathrm{O}_{3}$ and $\mathrm{CH}_{4}$ are reduced by about $10 \%$ and $18 \%$, respectively.

Through chemical interactions in the atmosphere, emissions affect climate indirectly via effects on gases with direct radiative effects on climate. An overview of mechanisms is given together with a preliminary assessment of the climatic impact of changes in tropospheric $\mathrm{O}_{3}$ and $\mathrm{CH}_{4}$ in response to emission increase. For a $10 \%$ increase in the $\mathrm{CH}_{4}$ emissions the relative increase in concentration has been estimated to be about $35 \%$ larger. Radiative forcing from enhanced levels of tropospheric $\mathrm{O}_{3}$ is estimated to be about $50 \%$ of the direct forcing from $\mathrm{CH}_{4}$. Inclusion of these indirect effects (including the effect on stratospheric $\mathrm{H}_{2} \mathrm{O}$ ) approximately doubles the climatic impact of $\mathrm{CH}_{4}$ emissions. The effect of $\mathrm{NO}_{x}$ emissions through changes in tropospheric $\mathrm{O}_{3}$ and $\mathrm{CH}_{4}$ are of opposite signs. The tropospheric levels of $\mathrm{O}_{3}$ are increased, while the levels of $\mathrm{CH}_{4}$ are reduced. For emissions of $\mathrm{NO}_{x}$ from aircraft, the positive effect via $\mathrm{O}_{3}$ changes are significantly larger than the negative through changes in $\mathrm{CH}_{4}$. For $\mathrm{NO}_{x}$ emitted from surface sources, the effects through changes in $\mathrm{O}_{3}$ and $\mathrm{CH}_{4}$ are estimated to be of similar magnitude and large uncertainty is connected to the sign of the next effect. Emissions of $\mathrm{CO}$ have a positive indirect effect on climate through enhanced levels of tropospheric $\mathrm{O}_{3}$ and increased lifetime of $\mathrm{CH}_{4}$.

We examined the effects of cirrus clouds on $\mathrm{O}_{3}$ photodissociation rates. The study evaluated the sensirivities of $O\left({ }^{1} D\right)$ and $O\left({ }^{3} P\right)$ photodissociation rates to optical thickness, cloud altitudes, solar zenith angle and surface reflectivity. The results showed that: above the cloud $O\left({ }^{\prime} D\right)$ rate increases versus clear sky condition and below the cloud the sigh of the change depends on the thickness of the cloud layer. Cloud alditude affects the magnitude of $O\left({ }^{1} D\right)$, but not on $O\left({ }^{3} P\right)$. The rate decreases as solar zenith angle increases under both clear and cloudy sky conditions. At large solar zenith angles, below-cloud rate is reduced even thongh the cloud layer is very thin; above-cloud rate is slightly increased. As surface reflectivity increases, the rate below a fairly thick cloud layer can be increased versus the clear sky condition.

A 2-D CTM of the global troposphere was used to study the chemical response to increased temperature and $\mathrm{H}_{2} \mathrm{O}$ caused by global waming. Increases in these climate variables reduce the levels of tropospheric $\mathrm{O}_{3}$ through temperature dependent reaction rates and increased production of odd hydrogen. In this case, the $\mathrm{CH}_{4}$ levels are also reduced. The results thus indicate that the considered mechanisms constirute a negative feedback effect on global warming.

A 3-D CTM was used to calculate the tropospheric $\mathrm{O}_{3}$ distribution using a variety of emission scenarios for $\mathrm{NO}_{x}, \mathrm{HC}$, and $\mathrm{CO}$. Changes in $\mathrm{O}_{3}$ and other gases consistently calculated from the CTMs were used to study the effect on radiative forcing and UV flux reaching the surface. These experiments were conducted for both the current climate state and the global warming climate state induced by increasing concentrations of greenhouse gases (such as $\mathrm{CO}_{2}, \mathrm{CH}_{4}, \mathrm{~N}_{2} \mathrm{O}$ and $C F C$ s). The results indicate that there is a strong differences in the seasonal and geographical distributions of $\mathrm{O}_{3}$ and radiative forcing perturbation. 


\subsection{Development of a Couplad Climate-Chemistry Model}

We continue the development of a coupled climate-chemistry global model. Progress is being made to incorporate a chemical code used in the University of Oslo's 3-D CTM into CCM3. The chemical code has been tested against a more accurate Gear code. The comparison shows that the distribution of the key gases in the $\mathrm{O}_{3}$ chemistry is accurately simulated. During the initial phase, we focus on the interface of input and output as well as the transport of trace species. In addition, in parallel to the coupled model development, we examine the consistency in the physical and chemical processes important to both climate and chemistry.

\section{Publications}

There were six (6) refereed journal articles, four (4) book articles, and two (2) proceedings manuscripts.

Berntsen, T., I. S. A. Isaksen, W.-C. Wang and X.-Z. Liang, 1996: Impacts of increased anthropogenic emissions in Asia on tropospheric ozone and climate: A global 3-D model study. Tellus, 48B, 13-32.

Berntsen, T., I. S. A. Isaksen, J. S. Fuglestvedt, G. Myhre, F. Stordal, R. S. Freckleton, and K. P. Shine, 1997: Effects of anthropogenic emissions on tropospheric ozone and its radiative forcing. Submitted to J. Geophys. Res.

Fuglestvedt, J. S., I. S. A. Isaksen, and W.-C. Wang, 1996: Estimates of indirect global warming potentials for $\mathrm{CH}_{4}, \mathrm{CO}$, and $\mathrm{NO}_{\times}$. Climatic Change, 34, 405-437.

Fuglestredt, J. S., J. E. Jonson, W.-C. Wang, and I. S. A. Isaksen, 1995: Responses in topospheric chemistry to changes in UV fluxes, temperatures and water vapor densities. in Atmospheric Ozone as a Climate Gas, (Eds) W.-C. Wang and I. S. A. Isaksen, 145-162, NATO ASI Series, Springer-Verlag, Berlin.

Fuglestvedt, J. S., T. K. Berntsen, I. S. A. Isaksen, H. Mao, X.-Z. Liang and W.-C. Wang, 1997: Impacts of reduced $\mathrm{NO}_{x}$ emissions on radiative forcing through changes in tropospheric $\mathrm{O}_{3}$ and $\mathrm{CH}_{4}$ : A global 3-D model study. Proceedings of XVIII Quadrennial Ozone Symposium96, September 12-21, 1996, L'Aquila, Italy.

Liang, X.-Z. and W.-C. Wang, 1995: A GCM study of the climatic effect of 1979-1992 ozone trend. Atmospheric Ozone as a Climate Gas, (Eds) W.-C. Wang and I. S. A. Isaksen, 259288, NATO ASI Series, Springer-Verlag, Berlin.

Mohnen, V. A., W. Goldstein, and W.-C. Wang, 1995a: A new challenge: Assessing tropospheric ozone as a climate gas. Atmospheric Environment, 29, 641-642.

Mohnen, V. A., W. Goldstein, and W.-C. Wang, 1995b: The potential role of tropospheric ozone as a climate gas. Bull. World Meteero. Org., 44., 38-42. 
Shine, K. P., B. P. Briegleb, A. S. Grossman, D. Hauglustaine, H. Mao, V. Ramaswamy, M. D. Schwarzkopf, R. Van Dorland, and W.-C. Wang, 1995: Radiative forcing due to changes in ozone: A comparison of different codes. Amospheric Ozone as a Climate Gas, (Eds) W.-C. Wang and I. S. A. Isaksen, 373-396, NATO ASI Series, Springer-Verlag, Berlin.

Wang, W.-C., H. Mao, I. S. A. Isaksen, J. S. Fuglestvedt, and S. Karlsdottir, 1997: Indirect Effects of Increasing Atmospheric Methane on the Radiative Forcing Through ClimateChemistry Interactions. Proceedings of XVurC Quadrennial Ozone Symposium-96, September 12-21, 1996, L'Aquila, Italy.

Wang, W.-C., M. P. Dudek, and X.-Z. Liang, 1995a: Chapter 9: The greenhouse effect of trace gases. 317-346, Future climates of the World, (Ed.) A. Henderson-Sellers, Elsevier Science Publ. Number 16 of the Wordd Survey of Climatology.

Wang, W.-C., X.-Ż. Liang, M. P. Dudek; D. Pollard and S. L. Thompson, 1995b: Atmospheric ozone as a climate gas. Atmospheric Research, 37, 247-256.

\section{Participation of Graduate Students}

Huiting Mao, a Ph.D. candidate at the Department of Earth and Atmospheric Sciences, SUNYA, has been studying radiative forcing and climate issues related to tropospheric $\mathrm{O}_{3}$. She is currently working on the study of the consistency of physical and chemical processes between the CTM and global climate model.

Jostein Sundet, a Ph.D. student at the Department of Geophysics, University of Oslo, has developed a new version of the CTM (OSLO CTM2) which will be used in the project. This model is flexible with regard to resolution (T21-T63) and uses the winds from ECWMF. Another Ph.D. student, Sigrun Karlsdottir, has studied $\mathrm{CH}_{4}$ feedback processes with 3-D CTM (OSLO CTMI) and the impact of climatic change (through changes in temperature and $\mathrm{H}_{2} \mathrm{O}$ ). 